\title{
LA-ICP-MS zircon U-Pb geochronology to constrain the age of post-Neocomian continental deposits of the Cerrillos Formation, Atacama Region, northern Chile: tectonic and metallogenic implications
}

\author{
Víctor Maksaev ${ }^{1}$, Francisco Munizaga ${ }^{1}$, Víctor Valencia ${ }^{2}$, Fernando Barra ${ }^{2}$ \\ ${ }^{1}$ Departamento de Geología, Universidad de Chile, Casilla 13518, Correo 21, Santiago, Chile. \\ vmaksaev@ing.uchile.cl; fmunizaga@cec.uchile.cl \\ 2 Department of Geosciences, University of Arizona, 1040 E. 4th Street, Bldg. \#77, Tucson, AZ 85721, USA. \\ victorv@email.arizona.edu; fbarra@email.arizona.edu
}

\begin{abstract}
New U-Pb zircon dating of volcanic intercalations in the lower conglomeratic part of the Cerrillos Formation shows that its deposition extended in time at least from $110.7 \pm 1.7$ to $99.7 \pm 1.6 \mathrm{Ma}$. The significantly younger $\mathrm{U}-\mathrm{Pb}$ zircon age of $69.5 \pm 1.0 \mathrm{Ma}$ obtained for the upper volcanic part of the Cerrillos Formation suggests recurrence of volcanism in the Late Cretaceous instead of continual volcanic activity. A minimum late Maastrichtian age for the Cerrillos Formation and its initial deformation was determined by the U-Pb zircon age range from $66.9 \pm 1.0$ to $65.2 \pm 1.0$ Ma for the lower part of the unconformably overlying Hornitos Formation. The new U-Pb data for the Cerrillos and Hornitos formations poses questions about the Campanian-Maastrichtian age range currently ascribed to the latter. The lower part of the Cerrillos Formation represents a major change in the sedimentary regime from previous marine carbonate sedimentation in a backarc basin until the late Aptian to subsequent coarse alluvial sedimentation and volcanism since the early Albian. The lower part of the Cerrillos Formation is interpreted as the development of coalescent alluvial fans thinning inland, accompanied by volcanism. These developed as the result of transpressive deformation and uplift of the area of the current Coastal Cordillera by late Aptian, leading to subsequent active erosion and sedimentation inland, along with the eastward shift of the magmatic foci in the region. A mineralizing period of $\mathrm{Cu}$-Au porphyries overlaps in time with the deposition of the Cerrillos Formation in northern Chile; marking also a significant change in the metallogeny of the Andes of northern Chile.
\end{abstract}

Keywords: Cretaceous, Andes, U-Pb Geochronology, Cerrillos Formation, Porphyry copper.

RESUMEN. Geocronología U-Pb en circón por LA-ICP-MS para circunscribir la edad de depósitos continentales post-neocomianos de la Formación Cerrillos, Región de Atacama, norte de Chile: implicancias tectónicas y metalogénicas. Nuevas dataciones U-Pb obtenidas para intercalaciones volcánicas en la parte inferior conglomerádica de la

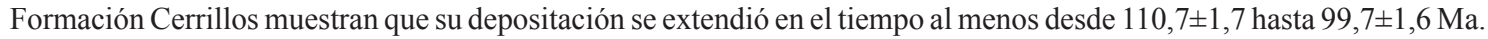
La edad U-Pb significativamente más joven de 69,5 $\pm 1,0$ Ma obtenida para la parte superior volcánica de la Formación Cerrillos, sugiere la recurrencia del volcanismo en el Cretácico Tardío, más que la continuidad de la actividad volcánica. Una edad mínima Maastrichtiano tardío para la Formación Cerrillos y su primera etapa de deformación se determinó por el rango de edades U-Pb de 66,9 $\pm 1,0$ a $65,2 \pm 1,0$ Ma para la parte inferior de la suprayacente, discordante Formación Hornitos. Los datos U-Pb para la Formación Hornitos plantean interrogantes respecto al rango Campaniano-Maastrichtiano actualmente asignado a esta unidad. La parte inferior de la Formación Cerrillos representa un cambio mayor en el régimen sedimentario desde la sedimentación previa calcárea marina en una cuenca de trasarco hasta el Aptiano tardío a una subsecuente sedimentación aluvial gruesa y volcanismo a partir del Albiano temprano. La parte inferior de la Formación Cerrillos se interpreta como conos aluviales coalescentes que se adelgazan hacia el interior continental acompañados de volcanismo. Su desarrollo estuvo ligado a la deformación transpresiva y alzamiento del área de la actual Cordillera de la Costa en el Aptiano tardío, lo que condujo a su erosión y sedimentación hacia el interior continental, junto con la migración hacia el este del eje magmático en la región. Un período de mineralización de pórfidos de Cu-Au se traslapa en el tiempo con la depositación de la Formación Cerrillos y marca también un cambio importante en la metalogénesis de Los Andes del norte de Chile. 


\section{Introduction}

The accurate dating of continental volcanosedimentary lithostratigraphic units in the Andes has traditionally been complicated by the lack of suitable mineral phases for reliable isotopic determinations and/or absence of paleontological material. Thus, the estimation of accurate ages for this type of units persisted as a significant problem of Chilean geology. In this way, the actual age range of the Cerrillos Formation remained uncertain, and as a matter of controversy, since its definition by Segerstrom and Parker (1959). The Cerrillos Formation is a succession of red conglomerate beds and volcanic rocks overlying Valanginian to late Aptian marine sedimentary strata of the Chañarcillo Group in the Atacama Region of northern Chile (Segerstrom and Ruiz, 1962; Marschik and Fonboté, 2001; Arévalo, 2005a, b; Mourgues, 2004, 2007). The continental coarse clastic alluvial sedimentation and coeval subaerial volcanism represented by the Cerrillos Formation marks an abrupt change from the previous marine carbonate sedimentation within an extensional backarc basin until late Aptian (e.g., Segerstrom and Parker, 1959; Zentilli, 1974; Jurgan, 1977; Pérez et al., 1990; Arévalo, 2005a, b; Mourgues, 2004, 2007). In recent publications the Cerrillos Formation was ascribed to the Albian-Turonian, based on its stratigraphic position over the marine fossiliferous Pabellón Formation of late Aptian minimum age, and unconformable under the volcanic Hornitos Formation attributed to the Campanian-Maastrichtian (Arévalo, 2005a, b). To better constrain the age of this unit and stress its significance in the geological evolution of the Andes of northern Chile, we dated volcanic rocks of the Cerrillos Formation and the overlying Hornitos Formation by the LA-ICP-MS $\mathrm{U}-\mathrm{Pb}$ method in zircon. The U-Pb system in zircon is a robust method for accurately assessing the crystallization ages of igneous rocks, due to the highest known closure temperature for $\mathrm{Pb}$ diffusion, which exceeds $900^{\circ} \mathrm{C}$ for zircons of typical sizes (Cherniak and Watson, 2000 and references therein), and the overall chemical resistance of zircon to alteration or metamorphism (e.g., Davis and Krogh, 2000). In addition, the laser ablation approach allows analyzing 35-50 $\mu \mathrm{m}$ diameter spots on individual zircon crystals and restricts the isotopic analyses to the portions of interest.

\section{Geological background}

The Cerrillos Formation was defined by Segerstrom and Parker (1959) in the area of the current Carrizalillo creek (formerly Cerrillos creek), $27 \mathrm{~km}$ southwest of Copiapó city in the Atacama Region (Fig. 1). The lower part of this formation is about $2,000 \mathrm{~m}$ thick; it is composed predominantly of red orthoconglomerate, paraconglomerate, and sandstone beds dipping east, with intercalations of tuffs, andesitic lava flows, breccias, agglomerates and volcanic avalanche deposits, and local levels of fresh-water limestone and siltstone. The conglomerate clasts are poorly sorted, rounded to subrounded, with boulders up to $1 \mathrm{~m}$ in diameter, which are composed primarily of andesitic porphyritic lavas, with a volcanic wacke matrix. The red sandstone beds are volcanic wackes containing andesitic material; ripple marks and desiccation cracks are common in the finer clastic intercalations (Segerstrom and Parker, 1959; Segerstrom, 1959). About 1,000 m above the base of the formation, in addition to andesitic clasts, the conglomerates contain limestone clasts with reworked marine fossils of HauterivianBarremian age (Segerstrom, 1968); these indicate denudation of Neocomian limestone strata during the sedimentation of the Cerrillos Formation. The red conglomeratic succession represents high-energy alluvial deposits, which are interpreted as coalescent alluvial fans. The provenance of the coarse clastic materials of the Cerrillos Formation is clearly from a prominent ground composed primarily of andesitic volcanic rocks, but where eventually Neocomian carbonate rocks were also exposed to erosion, either by progressive denudation and/or tectonism. The composition of the source terrain corresponds well to the rocks of the Jurassic to Early Cretaceous volcanic arc and its easterly interfingering with Neocomian carbonate strata (La Negra, Punta del Cobre and Bandurrias formations; e.g., Moscoso et al., 1982; Arévalo, 2005a, b), which are exposed immediately west from the Early Cretaceous backarc basin represented by the Chañarcillo Group. In contrast, the region to the east is formed of Upper Paleozoic to Triassic granitoids and mainly felsic volcanic rocks, and Jurassic sedimentary strata, none comparable to the composition of the clasts of the lower part of the Cerrillos Formation. 




FIG. 1. Sample location map showing the U-Pb zircon ages for the Cerrillos and Hornitos formations, respectively. Outcrop distribution of the marine carbonate rocks of the Neocomian Chañarcillo Group and the continental clastic and volcanic rocks of the Cerrillos and Hornitos formations is based on the 1:1.000.000 scale geological map of Chile (SERNAGEOMIN, 2002).

Farther south at the latitude of La Serena $\left(30^{\circ} \mathrm{S}\right)$, a 1,000-m-thick succession of continental coarse and fine sedimentary rocks and pyroclastic breccias is exposed. This succession contains fossil dinosaur bones, the remains of crocodiles and turtles, and abundant silicified tree stems (Quebrada La Totora Beds); this unit has been correlated with the Cerrillos Formation and assigned to the late Albian to Cenomanian by Pineda and Emparan (2006).

The upper part of the Cerrillos Formation is about 2,000 $\mathrm{m}$ in thickness and is dominated by andesitic lavas, breccias, agglomerates, and tuffs; the lavas are mostly porphyritic pyroxene-bearing andesites. The rocks are often chloritized, have abundant epidote, and appear greenish-grey to reddish-brown in outcrop. The volcanic rocks of the upper part of the Cerrillos Formation represent the development of a new subduction-related magmatic arc approximately located along the site of the former Early Cretaceous back-arc marine sedimentary basin of the Chañarcillo Group, thus marking an eastern shift of the magmatic foci.

The aggregate thickness of the Cerrillos Formation has been estimated to exceed 4,000 m (Segerstrom, 1959; Arévalo, 2005a, b). However, the Cerrillos Formation has strong thickness and lateral facies variations, owing to its coarse clastic continental and volcanic nature.

Segerstrom and Parker (1959) considered that the Cerrillos Formation unconformably overlies the Lower Cretaceous marine carbonate rocks of the Chañarcillo Group and also the underlying Bandurrias Formation farther north in the Paipote creek. In fact, the basal stratigraphic relationship of the Cerrillos Formation is obscured by thrust faults related to the Paipote thrust and fold system, which 
truncate strata (Arévalo, 1999, 2005a, b; Arévalo et al., 2006). At its type-locality there is no angular unconformity at the base of the Cerrillos Formation, but an erosional surface was inferred from the occurrence of limestone clasts with Neocomian marine fossils within the conglomerates (Arévalo, 2005a, b; Arévalo et al., 2006). On the other hand, the Cerrillos Formation is unconformably covered by the Hornitos Formation, which consists of a succession 2,200 m thick of breccias, tuffs, lavas and conglomerates with coarse sandstone matrix and lenticular intercalations of continental red sandstone, calcareous mudstone and limestone. Dacitic domes and minor rhyolitic ignimbritic intercalations are also present. At its top, a continuous member of basaltic and trachybasaltic lavas is developed (Arévalo, 2005a, b). Although separated by an unconformity, the similar continental sedimentary and volcanic nature, and marked lateral facies variations of the Cerrillos and Hornitos formations complicate the rightful identification and correlations of rocks of these units in the field.

The end of marine carbonate sedimentation in the back-arc basin and basin inversion by late Aptian correlates in time with geological evidences for the onset of left-lateral transpression at regional scale along the western Coastal Cordillera of northern Chile, where the magmatic arc was located at that time (Aguirre, 1985; Taylor et al., 1998; Randall and Taylor, 1996; Marschick and Fontboté, 2001; Marschick and Söllner, 2006). In the Coastal Cordillera area the north-south-trending Atacama Fault System, a major intra-arc, sinistral, strike-slip fault system, was active during the Early Cretaceous; it extends for more than $1,000 \mathrm{~km}$ from latitude $20^{\circ}$ to $30^{\circ} \mathrm{S}$, as attested by numerous faults and associated mylonite belts and foliated intrusions (Arabasz, 1971; Scheuber and Adriessen, 1990; Boric et al., 1990; Scheuber and González, 1999; Dallmeyer et al., 1996; Grocott and Taylor, 2002). However, a debate persists about the actual regional stress conditions on the continental border during the latest Early Cretaceous, because sinistral, transtensional faults provided conditions for emplacement of intrusions between $\sim 120$ and $93 \mathrm{Ma}$, as inferred from emplacement models of intrusive bodies and ${ }^{40} \mathrm{Ar} /{ }^{39} \mathrm{Ar}$ and $\mathrm{K}-\mathrm{Ar}$ dating of foliated intrusions and mylonites along the Coastal Cordillera (Grocott and Taylor, 2002; Arévalo 2005a, b; Arévalo et al., 2005, 2006). Accordingly, these authors favor instead a regional sinistral transtension during this time-span, and consider the onset of sinistral transpression to be post $77 \mathrm{Ma}$ (e.g., Grocott and Taylor, 2002). Although tensional and compressive zones may develop simultaneously along shear zones, the deposition of the Cerrillos Formation was interpreted as filling a narrow, subsident basin related to active extensional tectonics (Arévalo 2005a, b; Arévalo et al., 2005). This event was correlated with a poorly constrained in time, mid-Cretaceous extension oblique to the orogen, interpreted by Mpodozis and Allmendinger (1992, 1993) in the Sierra de Fraga of the Atacama Region. In addition, the lack of a 'strong' angular unconformity at the base of the Cerrillos Formation, and the fact that most contractional structures post-date this unit east of Copiapó, were taken by Arévalo et al. (2006) as evidences for discarding the major inversion of the back-arc basin at the time of the deposition of the Cerrillos Formation as proposed by Marschick and Fontboté (2001) and Marschick and Söllner (2006).

In our view, the change from marine carbonate sedimentation in the Early Cretaceous back-arc extensional basin to the subsequent subaerial deposition of coarse reddish conglomerates and volcanic rocks of the Cerrillos Formation during the late Aptian certainly represents an abrupt change in the sedimentary regime with time, which cannot be attributable to a variation of the sea-level according to the patterns of sea level change (Haq et al., 1988), neither to continual subsidence. It represents the sudden onset of vigorous erosion of andesitic volcanic rocks from the former Jurassic-Early Cretaceous magmatic arc, which provided clastic materials for the lower part of the Cerrillos Formation derived from the west, interpretation that is coincident with previous views for the provenance of clastic materials of this unit (e.g., Arévalo, 2005a, b). Therefore, the deposition of the Cerrillos Formation is not consistent with persistence of crustal attenuation related to extensional or transtensional tectonics in the region as interpreted by Arévalo (2005a, b). On the contrary, the deposition of the Cerrillos Formation is regarded here as consequence of orogenic tectonism on the active continental margin, leading to initiation of vigorous erosion of the area of the former subduction-related magmatic arc, accom- 
panied by continental alluvial sedimentation inland, back-arc basin inversion, and eastward migration of the magmatic front. In fact, this change was related to a major reorganization of the Andean orogen, which involved the closure of the back-arc basins all along the South American active continental margin, from Colombia to Southernmost Chile (Dalziel, 1986; Bourgois et al., 1987; Mpodozis and Ramos, 1990).

\section{Geochronology}

\subsection{Sampling strategy and zircon concentration}

To constrain both the initiation and the minimum age of the Cerrillos Formation, samples of volcanic rocks from this unit and from the lower part of the overlying unconformable Hornitos Formation were collected. Sampling was concentrated between latitudes $27^{\circ}$ and $29^{\circ} \mathrm{S}$ (Fig. 1), mostly within the areas of the Copiapó and Los Loros 1:100.000 scale geological maps (Arévalo, 2005a, b); the boundaries of the lithostratigraphic units sampled are those defined in these regional geological maps. Zircon separation was done by conventional methods in the Department of Geology of the Universidad de Chile; only half of the collected samples yielded zircon for $\mathrm{U}-\mathrm{Pb}$ dating.

\subsection{Analytical procedure for U-Pb dating}

The analytical work was done at the University of Arizona. Zircon concentrates of the $<350$ micron fraction were separated magnetically. Inclusionfree zircons from the non-magnetic fraction were then handpicked under a binocular microscope. At least fifty zircons from each sample were mounted in epoxy and polished until sectioned in half for laser ablation analyses. Previous to laser ablation ICP-MS analysis, zircons were studied under Scanning Electron Microscopy (SEM) by BSE and cathodoluminesence imaging in order to determine the complexity of the zircons. Zircon crystals were analyzed in polished section with a Micromass Isoprobe multi-collector ICP-MS equipped with nine Faraday collectors, an axial Daly detector, and four ion-counting channels (Dickinson and Gehrels, 2003). The Isoprobe is equipped with an ArF Excimer laser, which has an emission wavelength of $193 \mathrm{~nm}$. Analyses were conducted on 35-50 micron spots with output energy of $\sim 50 \mathrm{~mJ}$ (at $23 \mathrm{kV}$ ) and a repetition rate of $8 \mathrm{~Hz}$. Each analysis consisted of one 20 -second integration on peaks with no laser firing and twenty 1-second integrations on peaks with the laser firing. $\mathrm{Hg}$ contribution to the ${ }^{204} \mathrm{~Pb}$ mass position is accordingly removed by subtracting the on-peak background values. The depth of each ablation pit was $\sim 15-20$ microns. Total measurement time was $\sim 90$ s per analysis. The collectors were configured for simultaneous measurement of ${ }^{204} \mathrm{~Pb}$ in an ion counting channel while ${ }^{206} \mathrm{~Pb},{ }^{207} \mathrm{~Pb}$, ${ }^{208} \mathrm{~Pb},{ }^{232} \mathrm{Th}$, and ${ }^{238} \mathrm{U}$ were measured with Faraday detectors. All analyses were conducted in static mode. Inter-element fractionation was monitored by analyzing fragments of a large concordant zircon crystal from Sri Lanka with a known (ID-TIMS) age of $564 \pm 4 \mathrm{Ma}(2 \sigma)$ (Gehrels et al., 2008). This reference zircon was analyzed once for every three unknown samples. The reported ages for zircon grains are based on ${ }^{206} \mathrm{~Pb} /{ }^{238} \mathrm{U}$ ratios, because they are more reliable for young rocks than the ${ }^{207} \mathrm{~Pb} /{ }^{235} \mathrm{U}$ and ${ }^{206} \mathrm{~Pb} /{ }^{207} \mathrm{~Pb}$ ratios that present significantly higher errors. This is due primarily to the low intensity (commonly $<1 \mathrm{mV}$ ) of the ${ }^{207} \mathrm{~Pb}$ signal from these young, low-U grains. The ${ }^{206} \mathrm{~Pb} /{ }^{238} \mathrm{U}$ ratios are corrected for common $\mathrm{Pb}$ by using the measured ${ }^{206} \mathrm{~Pb} /{ }^{204} \mathrm{~Pb}$, common $\mathrm{Pb}$ composition from Stacey and Kramers (1975), and respective uncertainties of 1.0 and 0.3 for ${ }^{206} \mathrm{~Pb} /{ }^{204} \mathrm{~Pb}$ and ${ }^{207} \mathrm{~Pb} /{ }^{204} \mathrm{~Pb}$. For each sample, the ${ }^{206} \mathrm{~Pb} /{ }^{238} \mathrm{U}$ ages are plotted with 2 sigma error bars that reflect only the error from determining ${ }^{206} \mathrm{~Pb} /{ }^{238} \mathrm{U}$ and ${ }^{206} \mathrm{~Pb} /{ }^{204} \mathrm{~Pb}$. The weighted mean of each sample was calculated using the Isoplot program (Ludwig, 2003). For the final age of each sample, additional uncertainty from the calibration correction, decay constant, common lead composition and variation in measured ${ }^{206} \mathrm{~Pb} / 238 \mathrm{U}$ and ${ }^{206} \mathrm{~Pb} / 207 \mathrm{~Pb}$ of the standard are considered. These systematic errors (1.8-2.2\%) were added quadratically to the measurement error ( $\sim 0.98-2.2 \%)$. The reported ages are based primarily on ${ }^{206} \mathrm{~Pb} /{ }^{238} \mathrm{U}$ ratios for $<1000 \mathrm{Ma}$ grains and ${ }^{206} \mathrm{~Pb} /{ }^{207} \mathrm{~Pb}$ for $>1000 \mathrm{Ma}$ grains. All reported final ages and weighted mean ages have uncertainties at the two-sigma level. The results are summarized on table 1 , the respective bar graphs of ${ }^{206} \mathrm{~Pb} /{ }^{238} \mathrm{U}$ zircon ages for individual LA-ICP-MS analyses are shown in the figure 2, and analytical data are included in the Appendix 1. 

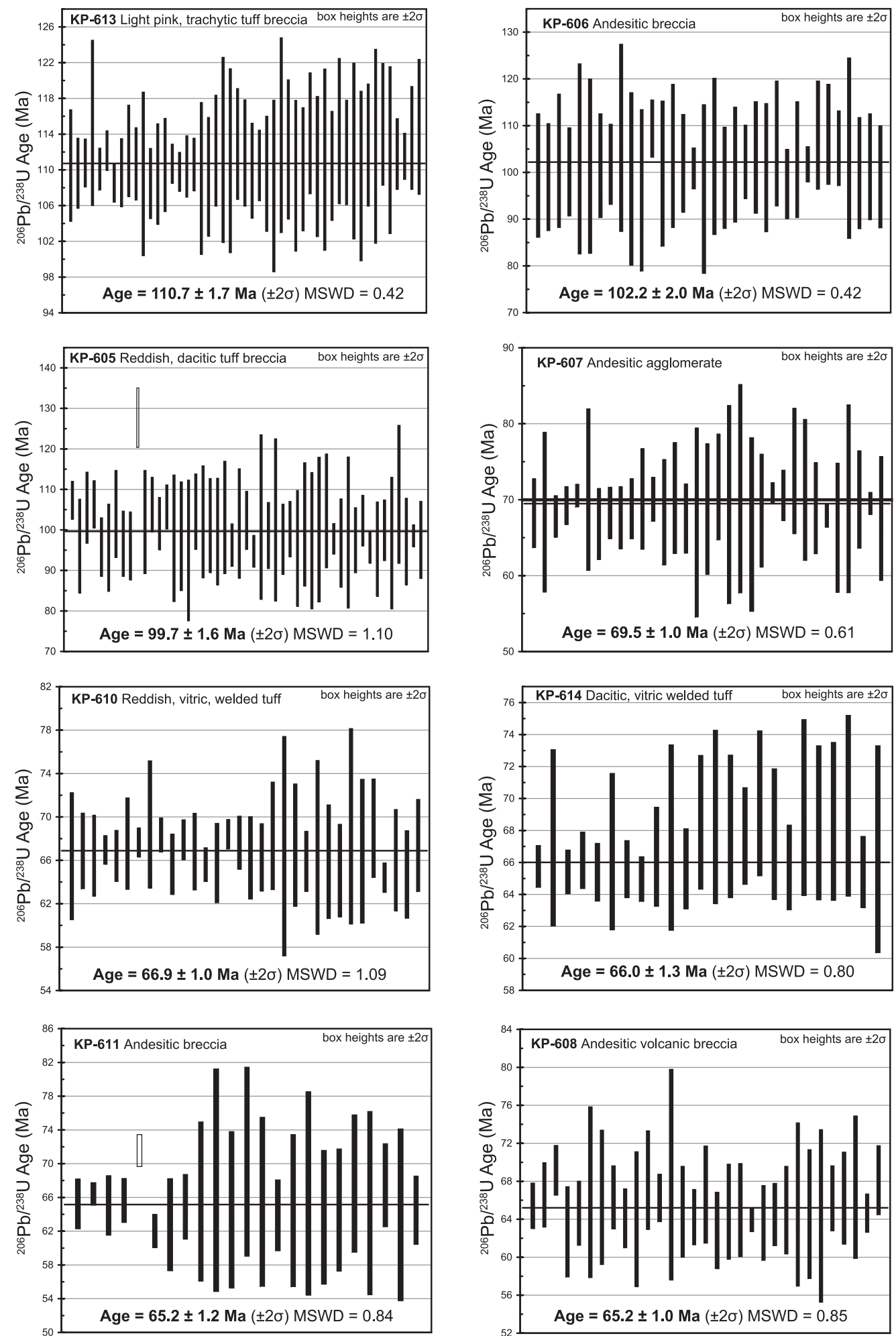

FIG. 2. Plots of ${ }^{206} \mathrm{~Pb} /{ }^{238} \mathrm{U}$ zircon ages for individual LA-ICP-MS analysis from the dated samples; the thick line shows the respective weighted average age (unshaded bars were excluded from age calculations; error bars are at $\pm 2 \sigma$ ). 


\subsection{Results}

A U-Pb zircon age of $110.7 \pm 1.7 \mathrm{Ma}$ was obtained for a light pink, trachyte, vitric, tuff breccia (KP-613; Table 1) intercalated within conglomerate beds dipping $10-15^{\circ} \mathrm{E}$, about 15 meters above the base of the Cerrillos Formation, near the locality of Molle Bajo (Fig. 1). This is the oldest isotopic age obtained for the Cerrillos Formation and probably representative of the initiation of clastic sedimentation and volcanic activity. In addition, a U-Pb zircon age of $102.2 \pm 2.0 \mathrm{Ma}$ (KP-606) was obtained for a large amygdaloidal (amygdules filled by celadonite and chalcedony) porhyrytic andesite block ( $1.5 \mathrm{~m}$ in diameter) from a coarse volcanic breccia horizon, intercalated into conglomerate beds dipping $30^{\circ} \mathrm{E}$, stratigraphically about $900 \mathrm{~m}$ above the base of the Cerrillos Formation at Paipote creek. In the same locality, another intercalation of reddish, dacitic, tuff breccia (KP-605), about $36 \mathrm{~m}$ higher in the stratigraphic succession relative to the previous sample, yielded a U-Pb zircon age of $99.7 \pm 1.6 \mathrm{Ma}$.

$\mathrm{A} U-\mathrm{Pb}$ zircon age of $69.5 \pm 1.0 \mathrm{Ma}$ was obtained for a porphyritic andesite block from an agglomerate (KP-607) from a volcanic succession gently dipping east $\left(15^{\circ} \mathrm{E}\right)$, immediately south of the Paipote creek, mapped as the upper part of the Cerrillos Formation by Segerstrom (1960) and Arévalo (2005a); this sample was collected about $2,900 \mathrm{~m}$ above the base of the succession exposed along the Paipote creek.
A U-Pb zircon age of $65.2 \pm 1.0$ Ma was obtained for a thick $(\sim 30 \mathrm{~m})$ massive horizon of grey andesite breccia (KP-608) that has been mapped by Arévalo (2005a) as the basal stratum of the Hornitos Formation in the San Miguel creek, near the confluence with the Paipote creek (Fig. 1). A reddish, vitric, welded tuff from the lower part of the Hornitos Formation (KP-610) yielded a U-Pb zircon age of $66.9 \pm 1.0 \mathrm{Ma}$ and a similar $\mathrm{U}-\mathrm{Pb}$ zircon age of $66.0 \pm 1.3 \mathrm{Ma}$ was obtained for another, reddish brown, vitric, dacitic welded tuff (KP-614) at the type-locality of the Hornitos Formation. The stratigraphic position of the two last samples is not exactly determined because the Hornitos Formation is folded and faulted and its base is not exposed at the sampling locations.

A U-Pb zircon age of $65.2 \pm 1.2 \mathrm{Ma}$ was obtained for an andesitic green breccia (abundant epidote and chlorite in the groundmass) with lithic fragments of porphyritic andesite and fragmented plagioclase crystals (KP-611). This sample was collected immediately above the Chañarcillo Group, from the basal part of an andesitic volcanic succession with conglomerate intercalations that overlies with angular unconformity the marine carbonate strata of the Neocomian Chañarcillo Group at Algarrobal creek (Fig. 1). This succession was mapped as the Cerrillos Formation by Abad (1980) and Moscoso et al. (1982), but its basal portion yielded a $\mathrm{U}-\mathrm{Pb}$ zircon age that is identical to those that we obtained for the Hornitos Formation.

TABLE 1. SUMMARY OF GEOCHRONOLOGICAL U-Pb ZIRCON DATA AND SAMPLE LOCATION.

\begin{tabular}{|c|c|c|c|c|c|c|}
\hline Sample & Lithology & Formation & $\begin{array}{l}\text { UTM North/East } \\
\text { (WGS 84) }\end{array}$ & $\begin{array}{l}\text { Altitude } \\
\quad \text { (m) }\end{array}$ & $\begin{array}{l}\text { Geodetic South/West } \\
\text { (PASAD 56) }\end{array}$ & $\begin{array}{c}{ }^{206} \mathrm{~Pb} /{ }^{238} \mathrm{U} \\
\text { zircon age } \\
(\mathrm{Ma} \pm \mathbf{2 \sigma})\end{array}$ \\
\hline KP-613 & Light pink, tuff breccia & Cerrillos & $6,919,925 / 371,183$ & 1,292 & $27^{\circ} 50^{\prime} 08.311^{\prime \prime} / 70^{\circ} 18^{\prime} 22.27^{\prime \prime}$ & $110.7 \pm 1.7$ \\
\hline KP-606 & Andesitic breccia & Cerrillos & $6,978,172 / 385,997$ & 657 & $27^{\circ} 18^{\prime} 40.47^{\prime \prime} / 70^{\circ} 09^{\prime} 01.05^{\prime \prime}$ & $102.2 \pm 2.0$ \\
\hline KP-605 & Reddish, dacitic, tuff breccia & Cerrillos & $6,978,098 / 386,068$ & 674 & $27^{\circ} 18^{\prime} 42.90^{\prime \prime} / 70^{\circ} 08^{\prime} 58.49^{\prime \prime}$ & $99.7 \pm 1.6$ \\
\hline KP-607 & Andesite agglomerate & Cerrillos & $6,977,054 / 391,015$ & 832 & $27^{\circ} 19^{\prime} 18.27^{\prime \prime} / 70^{\circ} 05^{\prime} 58.86^{\prime \prime}$ & $69.5 \pm 1.0$ \\
\hline KP-610 & Reddish, vitric, welded tuff & Hornitos & $6,921,318 / 380,770$ & 1,386 & $27^{\circ} 49^{\prime} 26.24^{\prime \prime} / 70^{\circ} 12^{\prime} 31.39^{\prime \prime}$ & $66.9 \pm 1.0$ \\
\hline KP-614 & Reddish-brown, welded tuff & Hornitos & $6,927,214 / 385,934$ & 840 & $27^{\circ} 46^{\prime} 16.28 ” / 70^{\circ} 09^{\prime} 20.63 \prime$ & $66.0 \pm 1.3$ \\
\hline KP-611 & Green andesitic breccia & Cerrillos(?) & $6,872,259 / 349,824$ & 680 & $28^{\circ} 15^{\prime} 48.82^{\prime \prime} / 70^{\circ} 31^{\prime} 44.76^{\prime \prime}$ & $65.2 \pm 1.2$ \\
\hline KP-608 & Andesitic volcanic breccia & Hornitos & $6,977,816 / 394,464$ & 903 & $27^{\circ} 18^{\prime} 54.48^{\prime \prime} / 70^{\circ} 03 ' 53.14 "$ & $65.2 \pm 1.0$ \\
\hline
\end{tabular}

\section{Discussion}

The U-Pb zircon age of $110.7 \pm 1.7 \mathrm{Ma}$ for a light pink tuff breccia intercalation near the base of the Cerrillos Formation indicates that the subaerial volcanic activity and alluvial sedimentation that formed this unit started in the early Albian. This is consistent with its stratigraphic position overlying 
the Pabellón Formation of late Aptian minimum age (Arévalo, 2005b). In addition, this is coherent with the U-Pb zircon age of $90.4 \pm 0.5$ Ma reported by Arévalo (2005b) for a dacite intrusion that crosscuts the lower part of the Cerrillos Formation near the locality of Molle Bajo. The alluvial sedimentation and volcanism of the lower part of the Cerrillos Formation extended in time at least to the latest Albian according to the $\mathrm{U}-\mathrm{Pb}$ zircon ages of $102.2 \pm 2.0$ and $99.7 \pm 1.6 \mathrm{Ma}$ obtained for volcanic rocks intercalated within conglomerates of the mid-part of the lower part of the Cerrillos Formation in the outcrops at the Paipote creek.

The U-Pb zircon age of $69.5 \pm 1.0$ Ma obtained for the upper volcanic part of the Cerrillos Formation immediately south of the Paipote creek is at least some $30 \mathrm{~m} . y r s$. younger than the ages obtained in the lower part of this formation. Although the east-dipping stratigraphic succession appears to be continuous along the Paipote creek, the large timespan suggests a recurrence rather than continuity of the volcanism extending up to the latest Campanianearliest Maastrichtian. On the other hand, this zircon $\mathrm{U}-\mathrm{Pb} 69.5 \pm 1.0 \mathrm{Ma}$ for volcanic rocks mapped by other authors as the upper part of the Cerrillos Formation is at variance with the Campanian-Maastrichtian age ascribed to the unconformable, overlying Hornitos Formation by Arévalo (2005a, b), and with the occurrence of Late Cretaceous fossil dinosaur remains described by Chong (1985) and Arévalo (2005b) within strata of the Hornitos Formation. Thus, either there is an erroneous delimitation of the Cerrillos Formation in the available geological maps or the age range assigned to the Hornitos Formation would need a revision.

We obtained a U-Pb zircon age of $65.2 \pm 1.0 \mathrm{Ma}$ (KP-608) for a thick massive stratum of andesitic breccia mapped by Arévalo (2005b) at the base of the Hornitos Formation in the San Miguel creek, near the confluence with the Paipote creek. The age is consistent with the higher stratigraphic position of this breccia horizon relative to the previous volcanic rocks that yielded 69.5 1.0 Ma. However, this radiometric age for the basal stratum of the Hornitos Formation indicates that the volcanic activity of this unit began at about the CretaceousTertiary boundary, at variance with the overall Campanian-Maastrichtian age ascribed to it by Arévalo (2005a, b), but also with strata containing Late Cretaceous fossil dinosaur remains described by Chong (1985) and Arévalo (2005b) as part of the Hornitos Formation. In addition, south of the Copiapó river valley we obtained a $\mathrm{U}-\mathrm{Pb}$ zircon age of $66.9 \pm 1.0 \mathrm{Ma}(\mathrm{KP}-610)$ for a reddish welded tuff horizon intercalation between conglomerate and red sandstone beds from the lower part of the Hornitos Formation. The exact stratigraphic position of this sample is hard to pinpoint due to the folding and faulting at this location, but the age is identical to other $\mathrm{U}-\mathrm{Pb}$ zircon age of $66.1 \pm 0.5 \mathrm{Ma}$ reported by Arévalo (2005b) for a similar tuff level some $8 \mathrm{~km}$ north. We also obtained a U-Pb age of $66.0 \pm 1.3$ $\mathrm{Ma}$ (KP-614) for another vitric, dacitic welded tuff from the type-locality of Hornitos in the Copiapó River valley, which is identical (within analytical error) to the above mentioned U-Pb ages, but also to a U-Pb zircon age of $65.6 \pm 0.2 \mathrm{Ma}$ obtained by Arévalo (2005b) for a dacite dome some $17 \mathrm{~km}$ to the NNE from Hornitos (Fig. 1).

Our new U-Pb dates from 67 to $65 \mathrm{Ma}$, coupled with a dozen of K-Ar dates between 65 and $50 \mathrm{Ma}$ compiled by Arévalo (2005a, b) strongly suggest that the Hornitos Formation represents volcanism and continental sedimentation that began in the latest Maastrichtian and developed mainly during the Paleogene, conflicting with the CampanianMaastrichtian age ascribed to this unit by Arévalo (2005a, b). In addition, the strata containing Late Cretaceous fossil dinosaur remains ascribed to the Hornitos Formation by Chong (1985), and Arévalo (2005b) is at variance with the new geochronological data obtained for the Cerrillos and Hornitos formations. Actually, the conflicting $\mathrm{U}-\mathrm{Pb}$ ages may partly be reconciled if rocks mapped as the upper volcanic part of the Cerrillos Formation by Segerstrom (1960) and Arévalo (2005a, b) would really belong to the Hornitos Formation. However, this alternative would involve changes to the geological cartography that are beyond the scope of this paper. It is apparent that the new $\mathrm{U}-\mathrm{Pb}$ data raise questions about the chronology of Hornitos Formation, the stratigraphic position of fossil dinosaur remains described by Chong (1985) and Arévalo (2005b), and to the delimitation of the continental stratified units of the Cerrillos and Hornitos formations.

$\mathrm{The} \mathrm{U}-\mathrm{Pb}$ geochronological data for the basal stratum and the lowermost part of the Hornitos Formation determine a latest Maastrichtian minimum age for the deposition and a first stage of deformation of the Cerrillos Formation, assuming correct delimitation of this unit in the current geological maps. 
The U-Pb zircon age of $65.2 \pm 1.2 \mathrm{Ma}$ obtained for a green andesite breccia from the basal part of a volcano-sedimentary succession at the Algarrobal Creek coincide with the U-Pb zircon ages for the basal part of the Hornitos Formation (Fig. 1). This succession was mapped as the Cerrillos Formation by Abad (1980) and Moscoso et al. (1982), but the isotopic age disagrees with this stratigraphic assignation. It is apparent that the continental sedimentary and volcanic nature of the Cerrillos and Hornitos formations and their marked lateral facies variations complicate mapping and correlations, particularly for extensive outcrops of rocks of the Cretaceous-Tertiary boundary, which unconformably overlie different older strata in the Atacama Region.

Our new geochronological U-Pb data substantiate that the sedimentation and coeval volcanism of the Cerrillos Formation began in the early Albian. The volcanism may have extended in time until $\sim 70 \mathrm{Ma}$, but the large time-span suggests recurrence instead of continual volcanic activity or misinterpretation in the identification of this unit in current geological maps. In addition, it is apparent that the deposition and initial deformation of the Cerrillos Formation were completed prior to $\sim 66 \mathrm{Ma}$, according the $\mathrm{U}-\mathrm{Pb}$ dates that we obtained for the basal rocks of the unconformably overlying Hornitos Formation (Fig. 1).

The lower part of the Cerrillos Formation represents continental, alluvial sedimentation during the Albian over the carbonate rocks of the Chañarcillo Group previously deposited within a marine back-arc basin. This significant change in the sedimentary regime cannot be attributable to a variation of the sea-level according to the patterns of sea level change (Haq et al., 1988). In our view, the coarse alluvial sedimentation is not consistent with persistence of extensional tectonics in the region as interpreted by Arévalo (2005a, b), because it signals surface uplift from marine to continental deposition, and consequent active erosion of the source region of the clastic materials of the Cerrillos Formation. Therefore, the lower part of this formation is regarded as the actual sedimentary record of orogenic tectonism on the active continental margin. The composition of the alluvial materials is consistent with a western provenance, as previously inferred by Arévalo (2005a, b), which corresponds to the area of the former magmatic arc currently forming the Coastal Cordillera. During the Albian active sinistral strikeslip faulting along the Coastal Cordillera coincides in time with the onset of compressive deformation that led to a major inversion of the Early Cretaceous intra- and back-arc basins in the late Aptian to Albian, in agreement with previous interpretations (e.g., Aguirre, 1985; Marschik and Fontboté, 2001; Marschick and Söllner, 2006). The simultaneous development of sinistral transtensional faults at that time (e.g., Grocott and Taylor, 2002; Arévalo 2005a, b; Arévalo et al., 2005, 2006) is considered to be a normal part of regional shearing deformation. It is apparent that the tectonism during the Aptian-Albian was concentrated within the magmatic arc on the active continental border, but not inland where the Cerrillos Formation was being deposited at that time, which explains the lack of an angular unconformity at the base of the Cerrillos Formation at its type locality. The occurrence of subsequent compressive structures in this unit is the result of the pattern of eastward migration of deformation with time, which follows the inland migration of the magmatic front in northern Chile (i.e., Rutland, 1971; Mortimer and Saric, 1975; Maksaev, 1990).

The lower clastic part of the Cerrillos Formation was interpreted by Arévalo (2005a, b) as tapering eastward in a series of steps limited by hypothetical normal faults related to active extensional tectonics. In our interpretation these faults are unnecessary, as the clastic rocks of the Cerrillos Formation represent coalescent alluvial fans thinning inland, which developed during the Albian, following the tectonic uplift of the former western magmatic arc and the concurrent emergence of the back-arc basin above the sea level. An eastward shift of the magmatic foci is also apparent from the volcanic intercalations in the lower conglomeratic part of the Cerrillos Formation and particularly by the upper volcanic part of this unit, but the $\sim 30$ m.yrs. difference between them suggest that the actual main eastward migration of the arc significantly postdated the alluvial sedimentation.

According to Segerstrom (1959; p. 12) the stratigraphic position of the Cerrillos Formation is equivalent to that of the Las Chilcas Formation in central Chile. This was confirmed by the Early Cretaceous age inferred by Rivano et al. (1986) for Las Chilcas Formation from K-Ar dating of intrusive rocks that crosscut the unit. In addition, Wall 
et al. (1999) and Sellés and Gana (2001) reported $\mathrm{U}-\mathrm{Pb}$ zircon ages in felsic volcanic rocks of the lower section of the Las Chilcas Formation in the $116.1 \pm 0.3$ to $106.5 \pm 0.4$ Ma range, whole-rock K-Ar ages of $101 \pm 3$ and $100 \pm 3 \mathrm{Ma}$ and a plagioclase K-Ar age of $95 \pm 3 \mathrm{Ma}$ for lavas of the upper stratigraphic levels of the Las Chilcas. These radiometric ages for Las Chilcas Formation are in the same range of the $\mathrm{U}-\mathrm{Pb}$ zircon ages that we obtained for the lower part of Cerrillos Formation.

The clastic rocks of the Las Chilcas Formation have been interpreted as syntectonic molasse deposits that accompanied the tectonic inversion of the Early Cretaceous marine basin in central Chile during a change from a rifted to a compressional margin in central Chile (Parada et al., 2005). This conclusion is in agreement with our interpretation of the clastic part of the Cerrillos Formation in the Atacama Region.

In the easternmost part of the Coastal Cordillera between latitudes $26^{\circ} 30^{\prime}$ to $30^{\circ} 30^{\prime} \mathrm{S}$ a belt of $\mathrm{Cu}-\mathrm{Au}$ porphyry deposits were formed from 108 to $88 \mathrm{Ma}$ (Maksaev et al., 2006a); this mineralizing period overlaps in time with the deposition of the Cerrillos Formation. Porphyry copper mineralization was virtually absent in earlier times of the evolution of the Andes of northern Chile, except for rare exceptions (i.e., Antucoya; Maksaev et al., 2006b). However, since the Albian porphyry-type deposits become the dominant type of mineral deposits. It appears that the orogenic tectonism that affected the continental margin during the late Aptian resulting in the inversion of the back-arc basin and an abrupt change in the sedimentary regime with time indicates also a significant change in Andean metallogeny.

\section{Conclusions}

The deposition of the conglomeratic lower part, 2,000 m thick, of the Cerrillos Formation extended in time at least from $110.7 \pm 1.7$ to Ma to $99.7 \pm 1.6$ $\mathrm{Ma}$ according to our new U-Pb zircon age data for volcanic intercalations. The volcanic activity may have continued until the $69.5 \pm 1.0$ Ma because of the $\mathrm{U}-\mathrm{Pb}$ zircon age obtained for the upper volcanic part of the Cerrillos Formation. However, the $\sim 30$ m.yrs. time-span relative to the above ages suggests a recurrence, rather than continuity of the volcanism. In addition, this $\mathrm{U}-\mathrm{Pb}$ zircon age falls into the $80-65$
Ma age range ascribed to the overlying Hornitos Formation by Arévalo (2005a, b), which poses questions about the accuracy of the age range ascribed to the Hornitos Formation, or alternatively, to the assignation of the dated rocks to the Cerrillos Formation. In any case, a minimum late Maastrichtian age for the Cerrillos Formation is established by the U-Pb zircon age range from $66.9 \pm 1.0$ to $65.2 \pm 1.0 \mathrm{Ma}$ for the lower part of the overlying Hornitos Formation (including a sample from its type-locality).

The U-Pb geochronological data indicates that the volcanism represented by the rocks mapped as Hornitos Formation started at about 67-65 Ma (Cretaceous-Tertiary boundary) and the overall geochronological data available strongly suggest that it represents primarily a Paleocene-Eocene volcanism. Due to the inconsistency with the Campanian-Maastrichtian fossil dinosaur remains in strata ascribed to the Hornitos Formation, the actual age range of the Hornitos Formation is considered still an open issue.

The lower part of the Cerrillos Formation represents a high energy, clastic, sedimentary accumulation within coalescent alluvial fans thinning inland, derived from the sudden accelerated erosion of the volcanic area to the west during the Albian, accompanied by andesitic volcanism related to the eastward shift of the magmatic arc. Therefore, the alluvial buildup becomes dominant in time in the area formerly occupied by the Neocomian marine sedimentary back-arc basin, accompanied by volcanic activity.

The deposition of the Cerrillos Formation resulted from the tectonic uplift during the middle to late Aptian of the area formerly occupied by the Early Cretaceous magmatic arc (current Coastal Cordillera) and the concurrent marine regression within the back-arc basin. This deformative episode was related to a major change from a rifted (extensional or transtensional) to a left-lateral compressional tectonic setting of the Chilean active continental margin, which represents a major paleogeographic change in the evolution of the Chilean Andes. This change of the tectonic setting was followed by a period of $\mathrm{Cu}-\mathrm{Au}$ porphyry mineralization along the easternmost part of the Coastal Cordillera of northern Chile, thus also marking a significant change in the metallogeny of the Chilean Andes. 


\section{Acknowledgments}

Conicyt, Chile, provided financial support for this study through Fondecyt Grant 1040492 to the first two authors. Petrographic observations of the dated rocks by $\mathrm{M}$. Brockway are very much appreciated. Comments provided by the reviewers Drs. R. Charrier, M. Basei and C. Arévalo helped to improve and clarify the manuscript, yet the interpretations of the data remain the sole responsibility of the authors.

\section{References}

Abad, E. 1980. Geología de los cuadrángulos Estación Algarrobal, Yerbas Buenas, Cerro Blanco, Merceditas y Tres Morros: Región de Atacama. Instituto de Investigaciones Geológicas, Carta Geológica de Chile 38: 38 p., escala 1:100.000.

Aguirre, L. 1985. The southern Andes. In The ocean basins and margins (Nairn, A.E.M.; Stelhi, F.G.; Uyeda, S.; editors). The Pacific Ocean, Plenum Press 7A: 265-376.

Arabasz, W. 1971. Geological and geophysical studies of the Atacama fault zone in northern Chile. Ph.D. Thesis (Unpublished), California Institute of Technology: $264 \mathrm{p}$.

Arévalo, C. 1999. The Coastal Cordillera/Precordillera Boundary in the Tierra Amarilla area (27 $20^{\prime}$ $\left.27^{\circ} 40^{\prime} \mathrm{S} / 70^{\circ} 05^{\prime}-70^{\circ} 20^{\prime} \mathrm{W}\right)$, northern Chile, and the structural setting of the Candelaria, $\mathrm{Cu}$-Au ore deposit: Ph.D. Thesis (Unpublished), Kingston-upon-Thames, U.K., Kingston University: 204 p.

Arévalo, C. 2005a. Carta Copiapó, Región de Atacama. Servicio Nacional de Geología y Minería, Carta Geológica de Chile, Serie Geología Básica 91: 54 p., escala 1: 100.000 .

Arévalo, C. 2005b. Carta Los Loros, Región de Atacama. Servicio Nacional de Geología y Minería, Carta Geológica de Chile, Serie Geología Básica 92: 54 p., escala 1:100.000.

Arévalo, C.; Mourgues, F.A.; Jaillard, E.; Bulot, L.G. 2005. Comparative evolution of the Lower Cretaceous Pluto-volcanic arc and back-arc from the Atacama Region, Chile. In International Symposium on Andean Geodynamics, No. 6, Extended Abstracts: 57-60. Barcelona.

Arévalo, C.; Grocott, J.; Martin, W.; Pringle, M.; Taylor, G. 2006. Structural setting of the Candelaria Fe oxide $\mathrm{Cu}-\mathrm{Au}$ deposit, Chilean Andes (27³0'S). Economic Geology 101: 819-841.

Boric, R.; Díaz, F.; Maksaev, V. 1990. Geología y yacimientos metalíferos de la Región de Antofagasta. Servicio Nacional de Geología y Minería, Boletín 40: $246 \mathrm{p}$.

Bourgois, J.; Toussaint, J.F.; González, H.; Azema, J.; Calle, B.; Desmet, A.; Murcia, L.; Acevedo, A.; Parra, E.; Tournon, J. 1987. Geological history of the Cretaceous ophiolitic complexes in northwestern
South America (Colombian Andes). Tectonophysics 143: 307-327.

Cherniak, D.J.; Watson, E.B. 2000. Pb diffusion in zircon. Chemical Geology 172: 5-24.

Chong, G. 1985. Hallazgo de restos óseos de dinosaurios en la Formación Hornitos -Tercera Región de Atacama, Chile. In Congreso Geológico Chileno, No. 4, Actas I: 152-161. Antofagasta.

Dallmeyer, R.D.; Brown, M.; Grocott, J.; Taylor, G.K.; Treolar, P.J. 1996. Mesozoic Magmatic and Tectonic Events within the Andean Plate Boundary Zone, $26^{\circ}$ $27^{\circ} 30^{\prime} \mathrm{S}$, North Chile: Constraints from ${ }^{40} \mathrm{Ar} /{ }^{39} \mathrm{Ar}$ Mineral Ages. The Journal of Geology, University of Chicago 104: 19-40.

Dalziel, I.W.D. 1986. Collision and Cordilleran orogenesis: An Andean perspective. In Collisional Tectonics (Coward, M.P.; Ries, A.C.; editors). Geological Society of London Special Publication 19: 389-404.

Davis, D.W.; Krogh, T.E. 2000. Preferential dissolution of ${ }^{234} \mathrm{U}$ and radiogenic $\mathrm{Pb}$ from $\alpha$-recoil-damaged lattice sites in zircon: implications for thermal histories and $\mathrm{Pb}$ isotopic fractionation in the near surface environment. Chemical Geology 172: 41-58.

Dickinson, W.R.; Gehrels, G.E. 2003. U-Pb ages of detrital zircons from Permian and Jurassic eolian sandstones of the Colorado Plateau, USA; paleogeographic implications. Sedimentary Geology.163: 29-66.

Gehrels, G.E.; Valencia, V.A.; Ruiz, J. 2008. Enhanced precision, accuracy, efficiency, and spatial resolution of $\mathrm{U}-\mathrm{Pb}$ ages by laser ablation-multicollector-inductively coupled plasma-mass spectrometry. Geochemistry, Geophysics, and Geosystems 9, Q03017, doi:10.1029/2007GC001805

Grocott, J.; Taylor, G.K. 2002. Magmatic arc fault systems, deformation partitioning and emplacement of granitic complexes in the Coastal Cordillera, north Chilean Andes (25 $30^{\prime}$ 'S to $27^{\circ} 00^{\prime}$ S ). Journal of the Geological Society of London 159: 425-442.

Haq, B.U.; Hardenbol, J.; Vail, P.R. 1988. Mesozoic and Cenozoic chronostratigraphy and cycles of sea level change. In Sea-level Change: an Integrated Approach (Wilgus, C.K.; Hastings, B.J.; Posamentier, H.; van Wagoner, J.C.; Ross, C.A.; Kendall, C.G.St.C.; editors). Society of Economic Paleontologists and Mineralogists, Special Publication 42: 71-108.

Jurgan, H. 1977. Zur Gliederung der Unterkreide-Serien in der Provinz Atacama, Chile. Geologische Rundschau 66: 404-434.

Ludwig, K.R. 2003. User's manual for Isoplot/Ex version 3.0, a geochronological toolkit for Microsoft Excel. Berkeley Geochronology Center, Special Publication 4. California.

Maksaev, V. 1990. Metallogeny, geological evolution and thermochronology of the Chilean Andes between latitudes $21^{\circ}$ and $26^{\circ}$ south, and the origin of the major porphyry copper deposits. Ph.D. Thesis(Unpublished), Dalhousie University: 554 p. Halifax, Canada. 
Maksaev, V.; Munizaga, F.; Valencia, V.; Barra, F.; McWilliams, M.; Mathur, R. 2006a. Geochronology of Cretaceous porphyry copper deposits of the Coastal Cordillera of northern Chile (latitudes 26 $30^{\prime}$ to $\left.30^{\circ} 30^{\prime} \mathrm{S}\right)$. Geological Society of America Abstracts with Programs 38 (7): 347.

Maksaev, V.; Munizaga, F.; Fanning, M.; Palacios, C.; Tapia, J. 2006b. SHRIMPU-Pb dating of the Antucoya porphyry copper deposit: new evidence for an Early Cretaceous porphyry-related metallogenic epoch in the Coastal Cordillera of northern Chile. Mineralium Deposita 41: 637-644.

Marschik, R.; Fontboté, L. 2001. The Candelaria-Punta del Cobre iron oxide $\mathrm{Cu}-\mathrm{Au}(\mathrm{Zn}-\mathrm{Ag})$ deposits, Chile. Economic Geology 96: 1799-1826.

Marschik, R.; Söllner, F. 2006. Early Cretaceous U-Pb zircon ages for the Copiapó plutonic complex and implications for the IOCG mineralization at Candelaria, Atacama, Region, Chile. Mineralium Deposita 41: 785-801.

Mortimer, C.; Saric, N. 1975. Cenozoic studies in northernmost Chile. Geologische Rundschau B 64: 395-420.

Moscoso, R.; Nasi, C.; Salinas, P. 1982. Hoja Vallenar y parte norte de La Serena, Regiones de Atacama y Coquimbo. Servicio Nacional de Geología y Minería, Carta Geológica de Chile 55: 100 p., escala $1: 250.000$

Mourgues, A. 2004. Advances in ammonite biostratigraphy of the marine Atacama basin (Lower Cretaceous), northern Chile, and its relationship with the Neuquén basin, Argentina. Journal of South American Earth Sciences 17: 3-10.

Mourgues, A. 2007. Paleontologie stratigraphique (Ammonites) et évolution téctono-sedimentaire du bassin d'arrière arc de Chañarcillo (Berriasien-Albien, Nord du Chili). Tesis de Doctorado (Unpublished), Université Toulouse III-Paul Sabatier, U.F.R. Sciences de la vie et de la terre: 295 p. Toulouse, France.

Mpodozis, C.; Allmendinger, R.W. 1992. Extensión cretácica a gran escala en el norte de Chile (PuquiosSierra de Fraga, $27^{\circ}$ L.S.): Significado para la evolución tectónica de los Andes. Revista Geológica de Chile 19 (2): 167-197.

Mpodozis, C.; Allmendinger, R.W. 1993. Extensional tectonics, Cretaceous Andes, northern Chile $\left(27^{\circ} \mathrm{S}\right)$. Geological Society of America Bulletin 105: 14621477.

Mpodozis, C.; Ramos, V. 1990. The Andes of Chile and Argentina. Circum-Pacific Council for Energy and Mineral Resources. Earth Science Series 11: 59-90.

Pérez, E.; Cooper, M.R.; Covacevic, V. 1990. Ammonite-based age for the Pabellón Formation, Atacama Region, northern Chile. Revista Geológica de Chile 17 (2): 181-186.

Parada, M.A.; Féraud, G.; Fuentes, F.; Aguirre, L.; Morata, D.; Larrondo, P. 2005. Ages and cooling history of the Early Cretaceous Caleu pluton: testimony of a switch from a rifted to a compressional continental margin in central Chile. Journal of the Geological Society of London 162: 273-287.

Pineda, G.; Emparán, C. 2006. Geología del área VicuñaPichasca, Región de Coquimbo. Servicio Nacional de Geología y Minería, Carta Geológica de Chile, Serie Geología Básica 97: 40 p., escala 1:100.000.

Randall, D.E.; Taylor, G.K. 1996. Major crustal rotations in the Andean margin: Paleomagnetic results from the Coastal Cordillera of northern Chile. Journal of Geophysical Research 101: 15783-15798.

Rivano, S.; Sepúlveda, P.; Boric, R.; Hervé, M.; Puig, A. 1986. Antecedentes radiométricos para una edad cretácica inferior de la Formación Las Chilcas. Revista Geológica de Chile 27 (1): 27-32.

Rutland, R.W.R. 1971. Andean orogeny and ocean floor spreading. Nature 233: 252-255.

Scheuber, E.; Andriessen, P.A.M. 1990. The kinematic and geodynamic significance of the Atacama fault zone, northern Chile. Journal of Structural Geology 12: 243-257.

Scheuber, E.; González, G. 1999. Tectonics of the Jurassic-Early Cretaceous magmatic arc of the North Chilean Coastal Cordillera $\left(22^{\circ}-26^{\circ} \mathrm{S}\right)$ : a story of crustal deformation along a convergent plate boundary. Tectonics 18: 895-910.

Segerstrom, K. 1959. Cuadrángulo Los Loros. Instituto de Investigaciones Geológicas, Carta Geológica de Chile 1: 33 p., escala 1:50.000.

Segerstrom, K. 1960. Cuadrángulo Quebrada Paipote, Provincia de Atacama. Instituto de Investigaciones Geológicas, Carta Geológica de Chile 3: 55 p., escala 1:50.000.

Segerstrom, K. 1968. Geología de las Hojas Copiapó y Ojos del Salado, Provincia de Atacama. Instituto de Investigaciones Geológicas, Carta Geológica de Chile 24: 58 p., escala 1:250.000.

Segerstrom, K.; Parker, R.L. 1959. Cuadrángulo Cerrillos, Provincia de Atacama. Instituto de Investigaciones Geológicas, Carta Geológica de Chile 2: 33 p., escala 1:50.000.

Segerstrom, K.; Ruiz, C. 1962. Cuadrángulo Copiapó, Provincia de Atacama. Instituto de Investigaciones Geológicas, Carta Geológica de Chile 6: 42 p., escala 1:50.000.

Sellés, D.; Gana, P. 2001. Geología del área Talagante-San Francisco de Mostazal: Regiones Metropolitana y del Libertador General Bernardo O'Higgins. Servicio Nacional de Geología y Minería, Carta Geológica de Chile, Serie Geología Básica 74: 30 p., escala 1:100.000.

SERNAGEOMIN, 2002. Mapa Geológico de Chile. Servicio Nacional de Geología y Minería, Carta Geológica de Chile, Serie Geología Básica 75, escala 1:1.000.000, 1 mapa en 3 hojas. Santiago.

Stacey, J.S.; Kramers, J.D. 1975. Approximation of terrestrial lead isotope evolution by a two-stage model. Earth and Planetary Science Letters 26 (2): 207-221. 
Taylor, G.K.; Grocott, J.; Pope, A.; Randall, D.E. 1998. Mesozoic fault systems, deformation and fault block rotation in the Andean forearc: a crustal scale strikeslip duplex in the Coastal Cordillera of northern Chile. Tectonophysics 299: 93-109.

Wall, R.; Sellés, D.; Gana, P. 1999. Área Tiltil-Santiago, Región Metropolitana. Servicio Nacional de Geología y Minería, Mapas Geológicos 11: 17 p. 1 mapa escala $1: 100.000$.

Zentilli, M. 1974. Geological Evolution and metallogenic relationships in the Andes of northern Chile, between $26^{\circ}$ and $29^{\circ}$ South. Ph.D. Thesis (Unpublished), Queen's University: 446 p. Kingston, Canada.

Manuscript received: April 18, 2008; revised/accepted: March 9, 2009. 


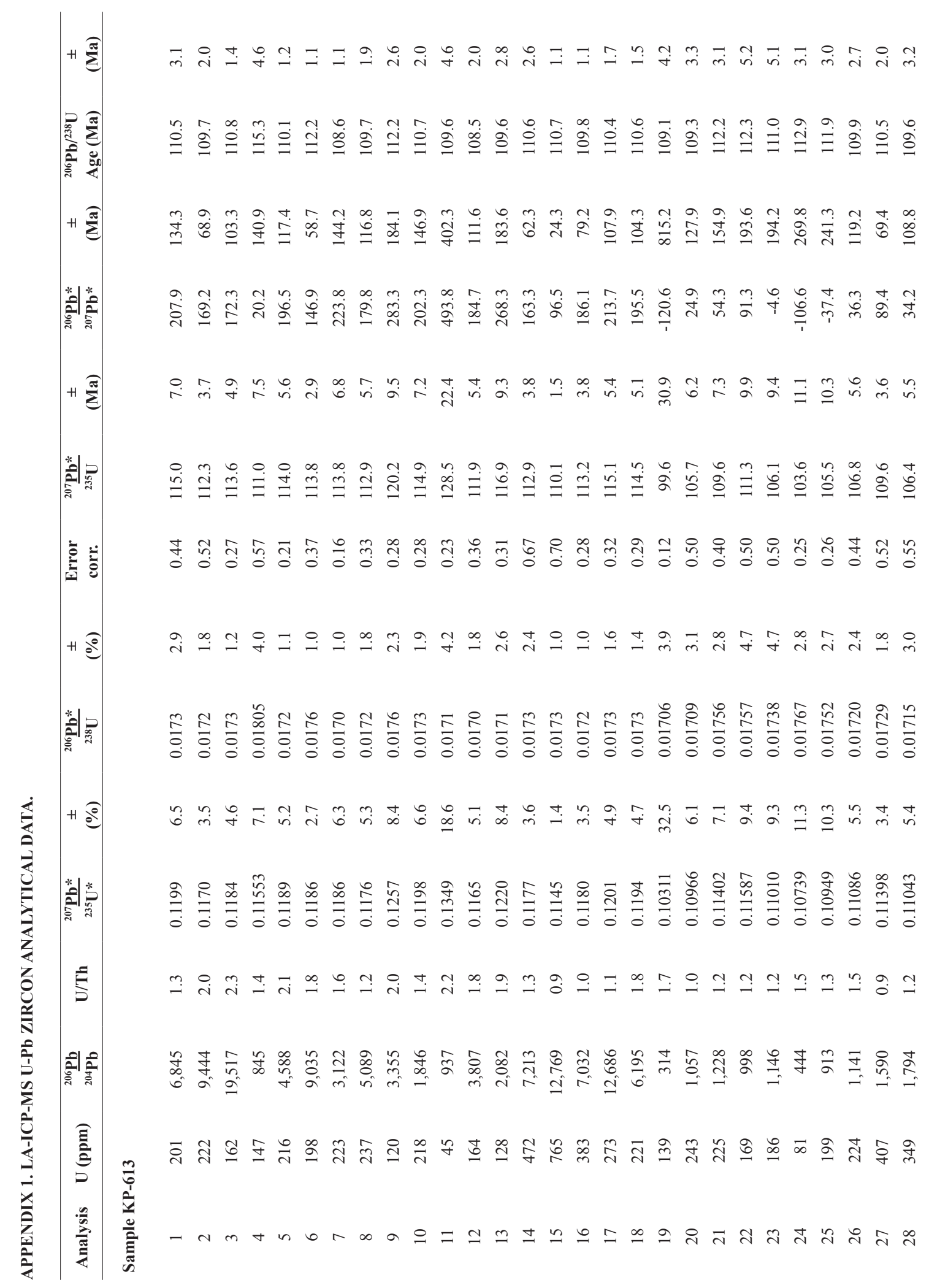




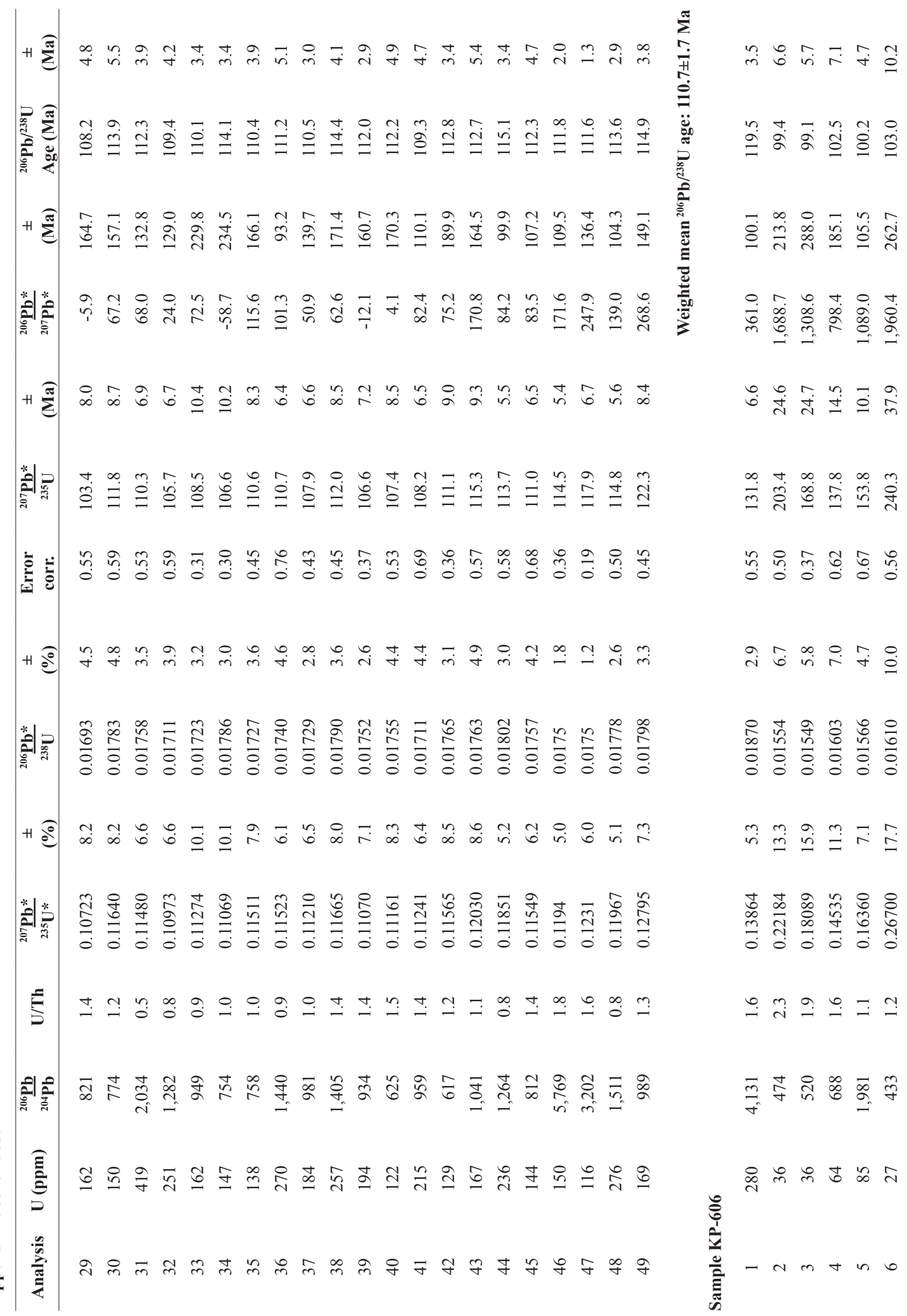






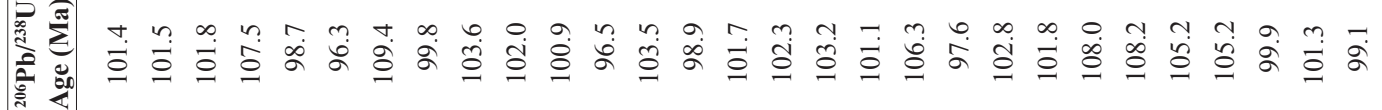

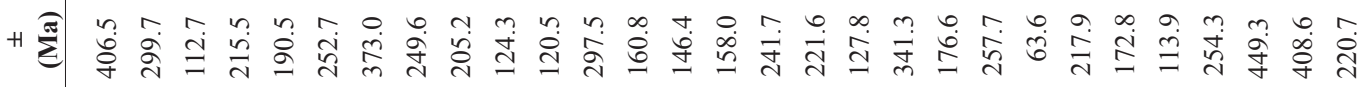



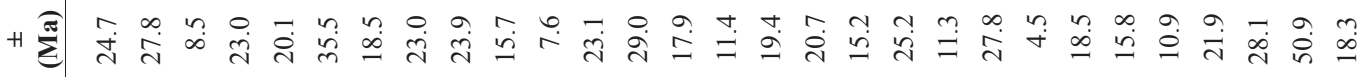

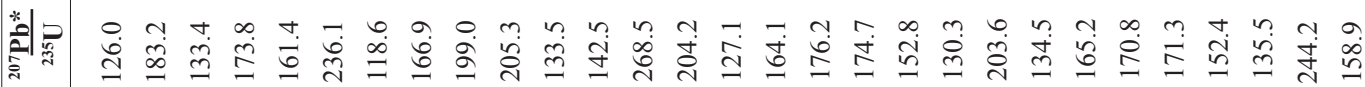

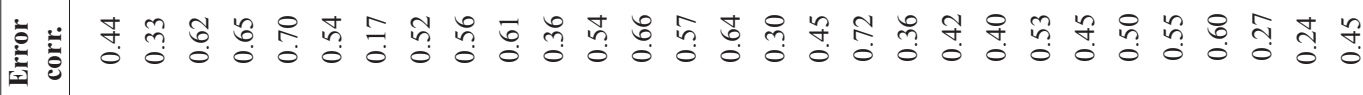

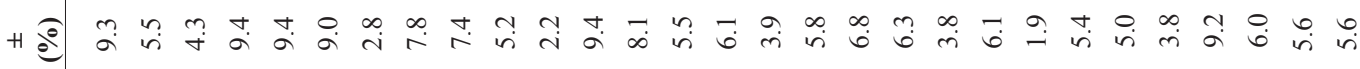

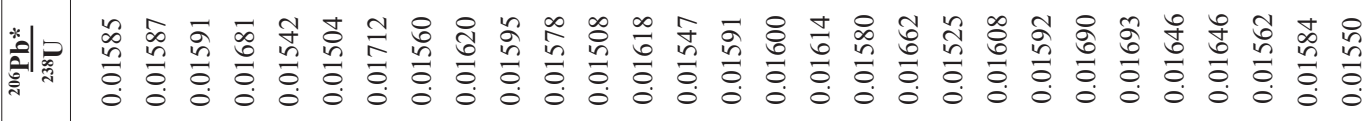
+ 0 @

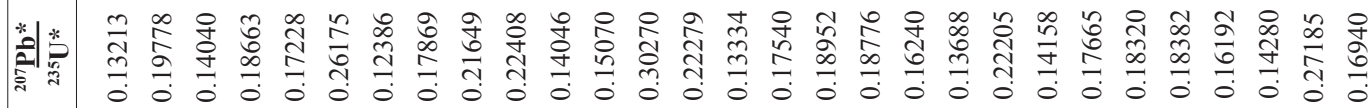
ह

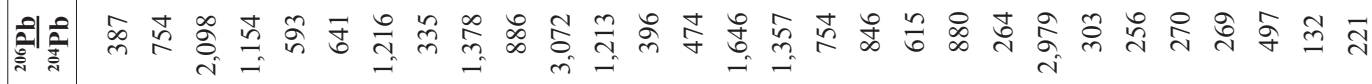
:

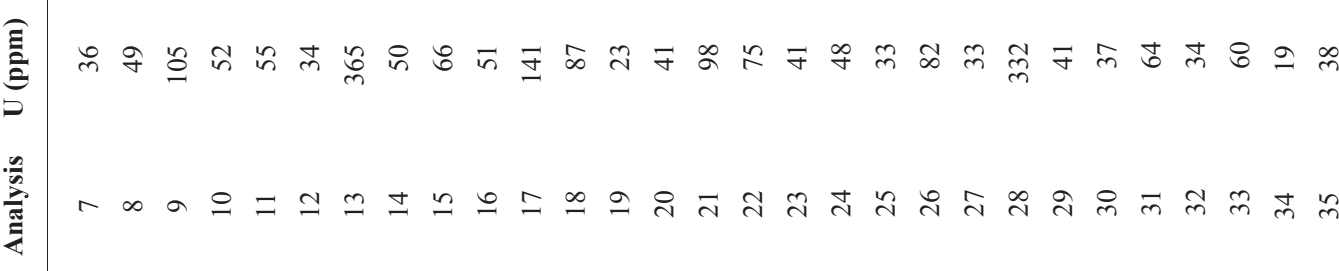




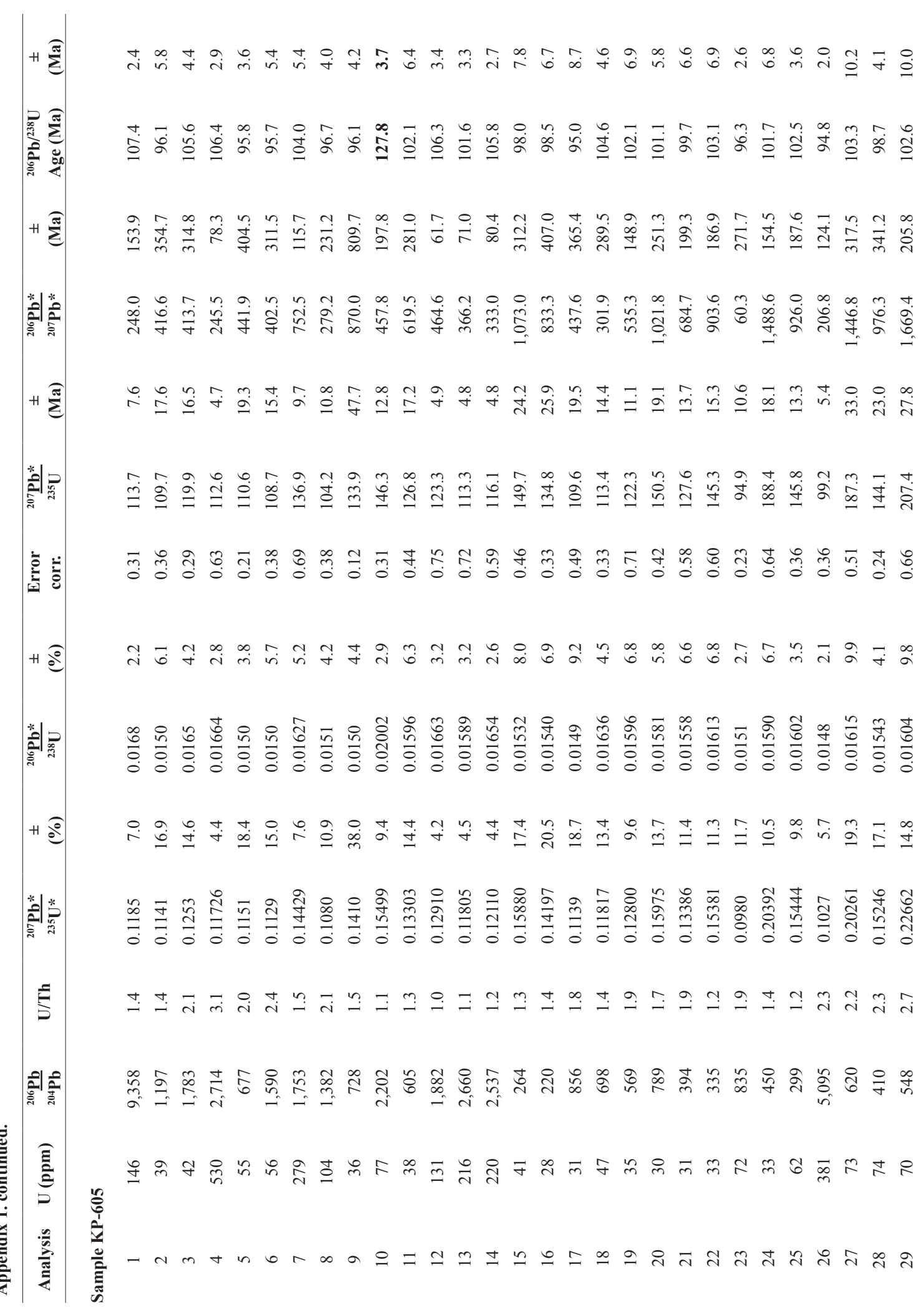






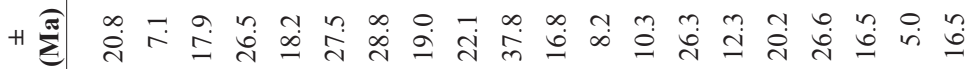

节

:

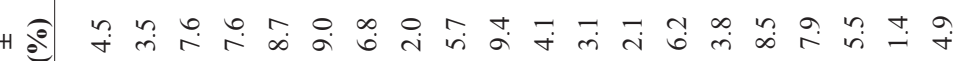



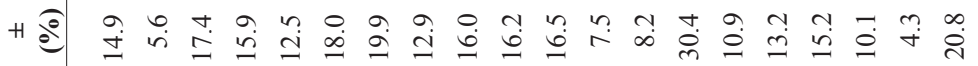

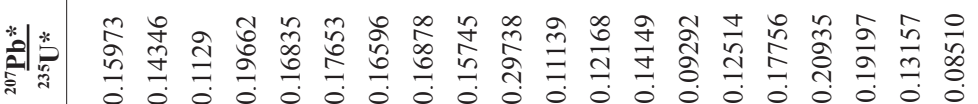

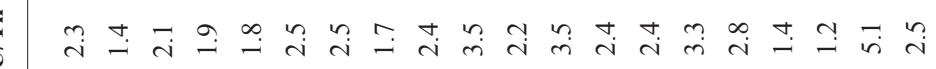

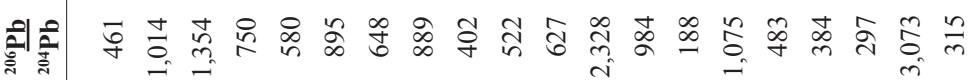



m

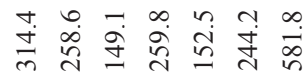

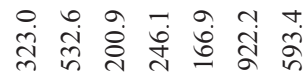

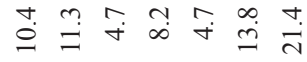

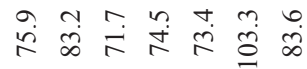

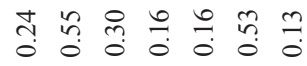

$m \stackrel{m}{m} \stackrel{\infty}{-} \cong \stackrel{n}{n}$

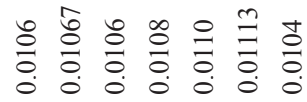

サ ‡

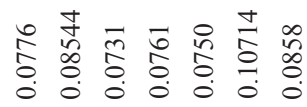

구요



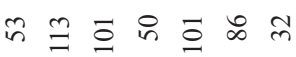

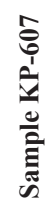




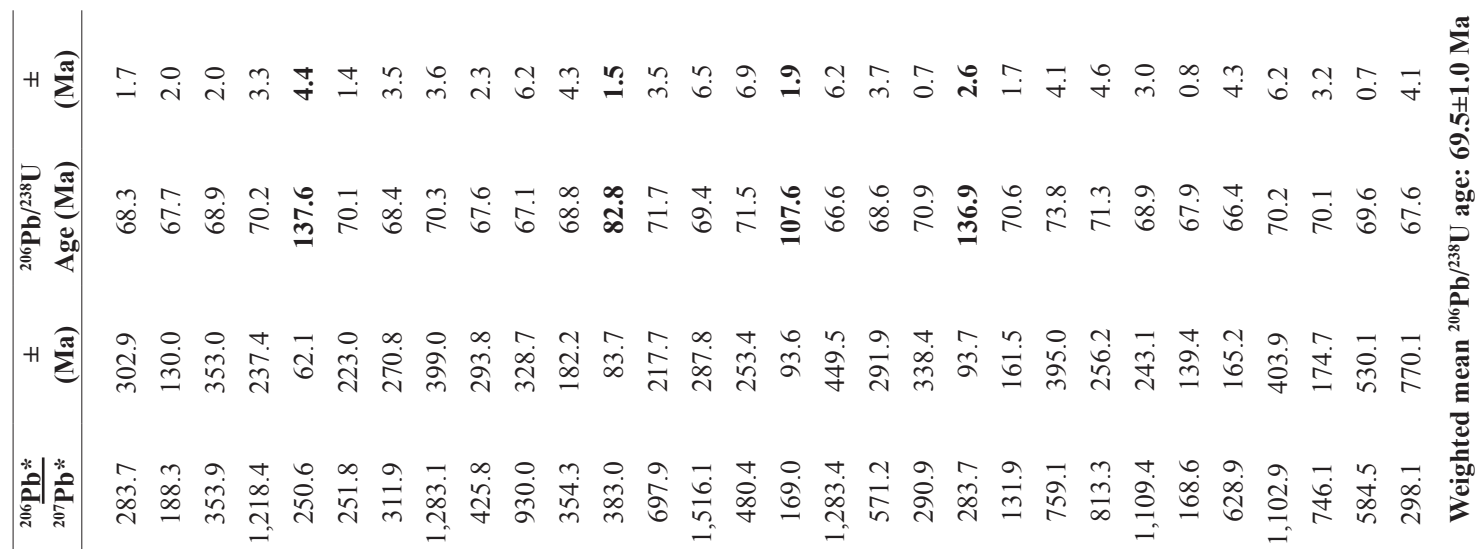

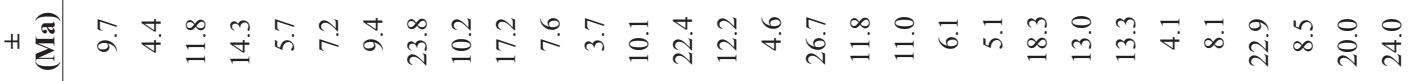

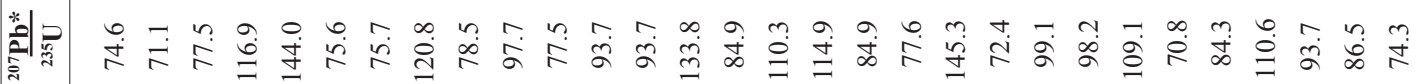

t)

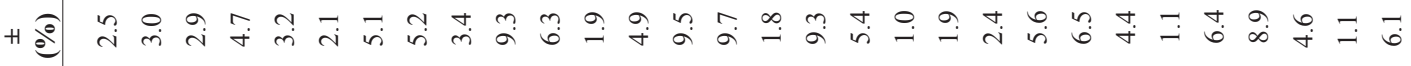

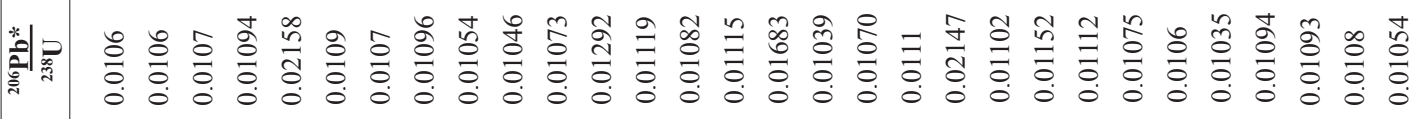

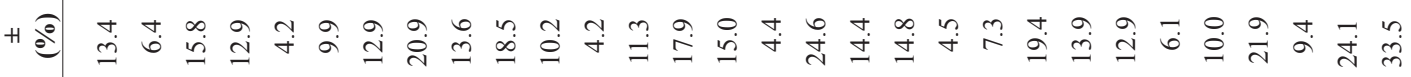

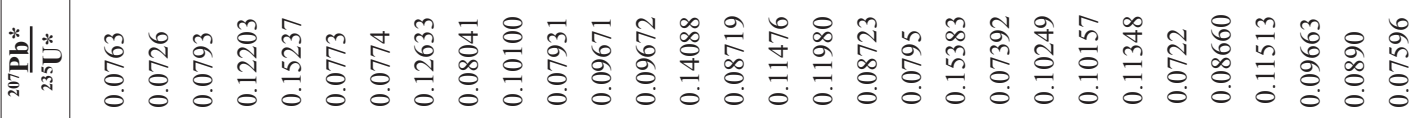



䨔育

ก

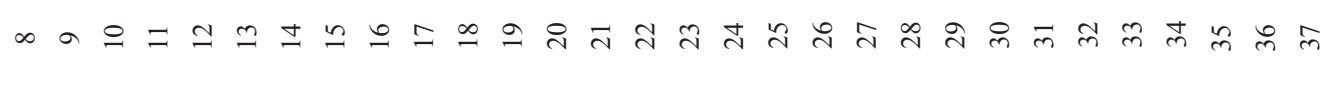









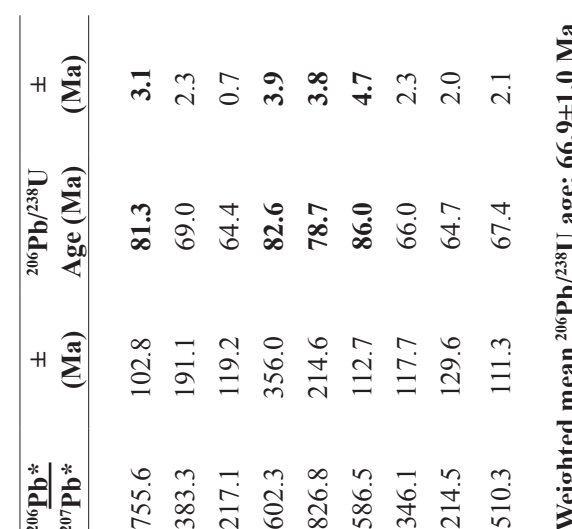

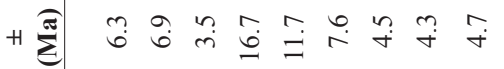

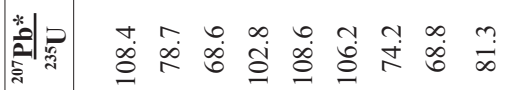

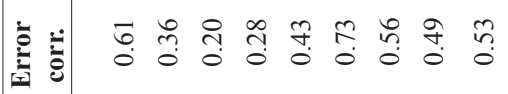

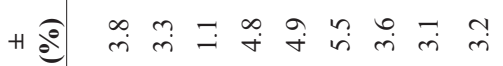

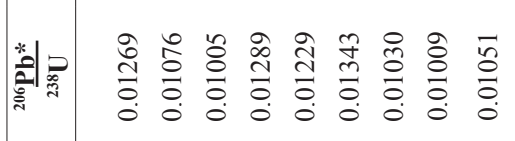

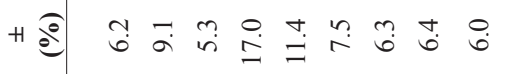



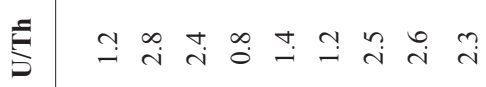



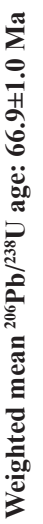



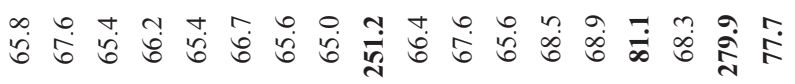

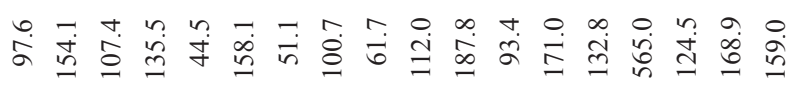

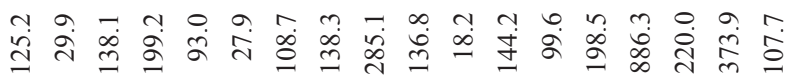



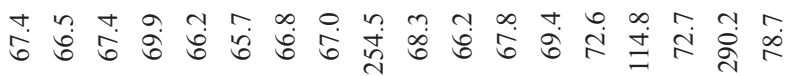

กิ

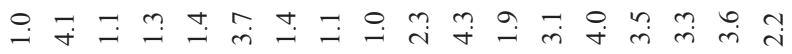





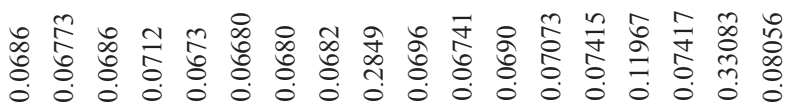

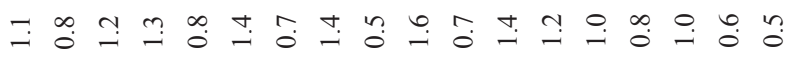



તૈ 


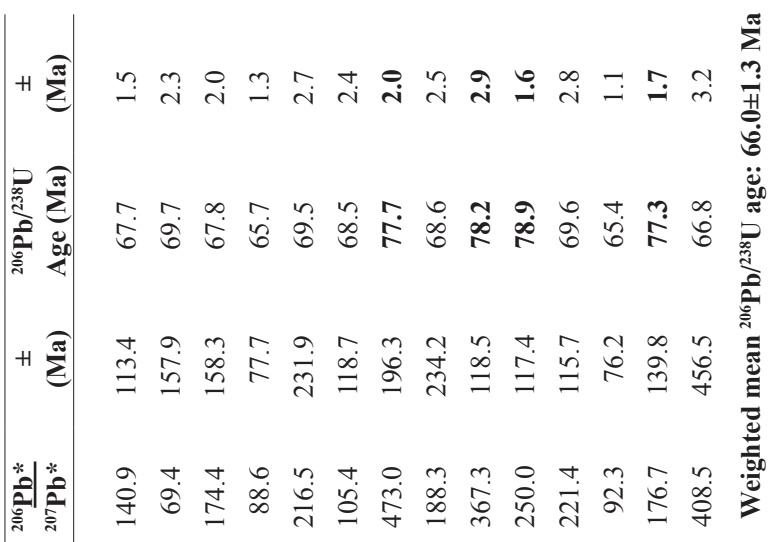

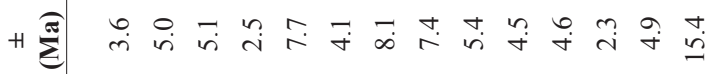

数

柔

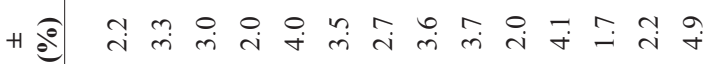

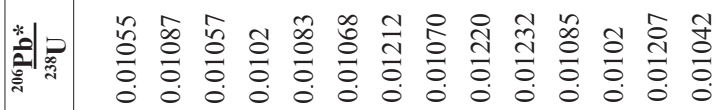

H

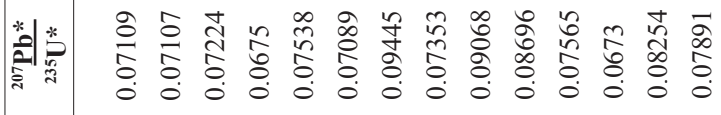

F

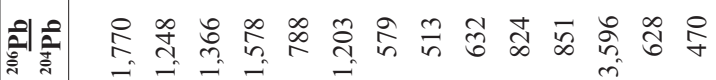

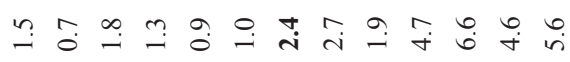

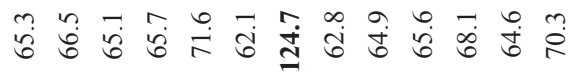

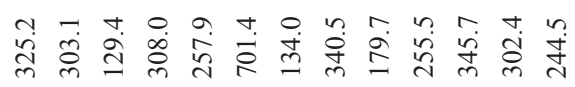

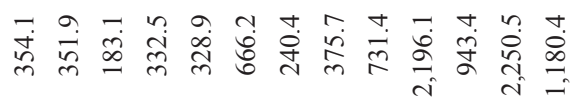

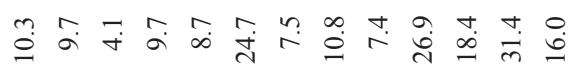



응

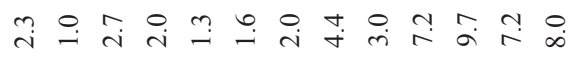

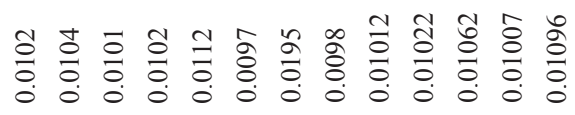

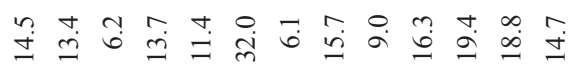

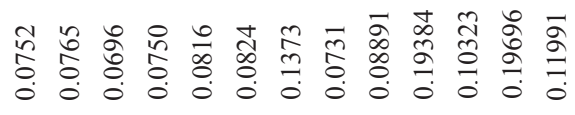

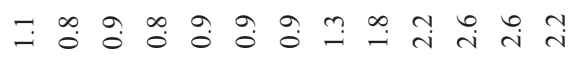

娄

유ำ 




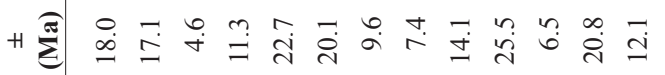

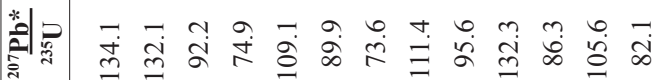

t)

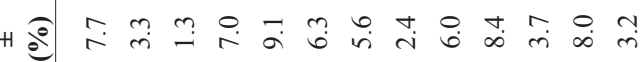

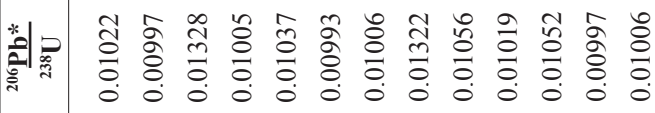

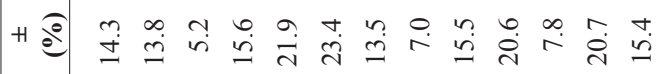

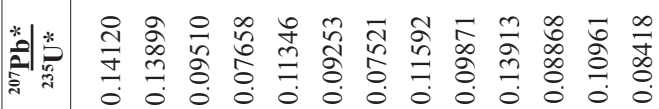





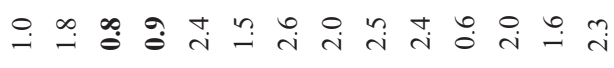

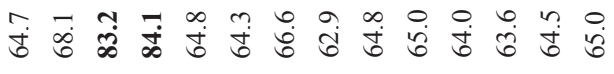

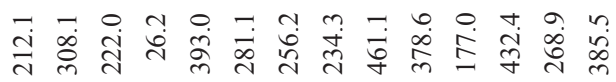

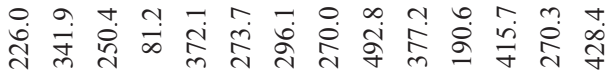

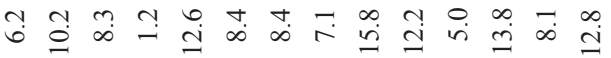

वें

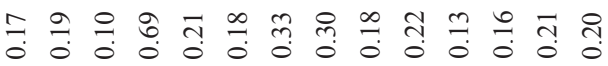

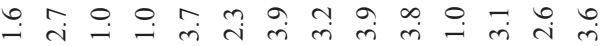

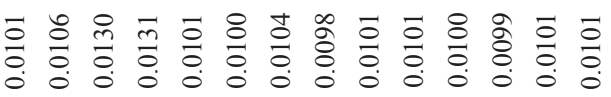

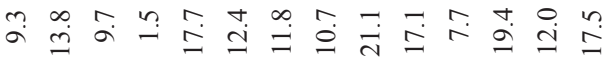



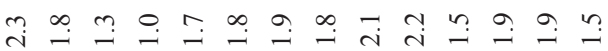



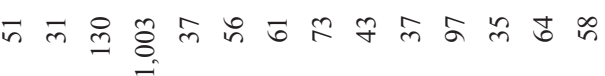




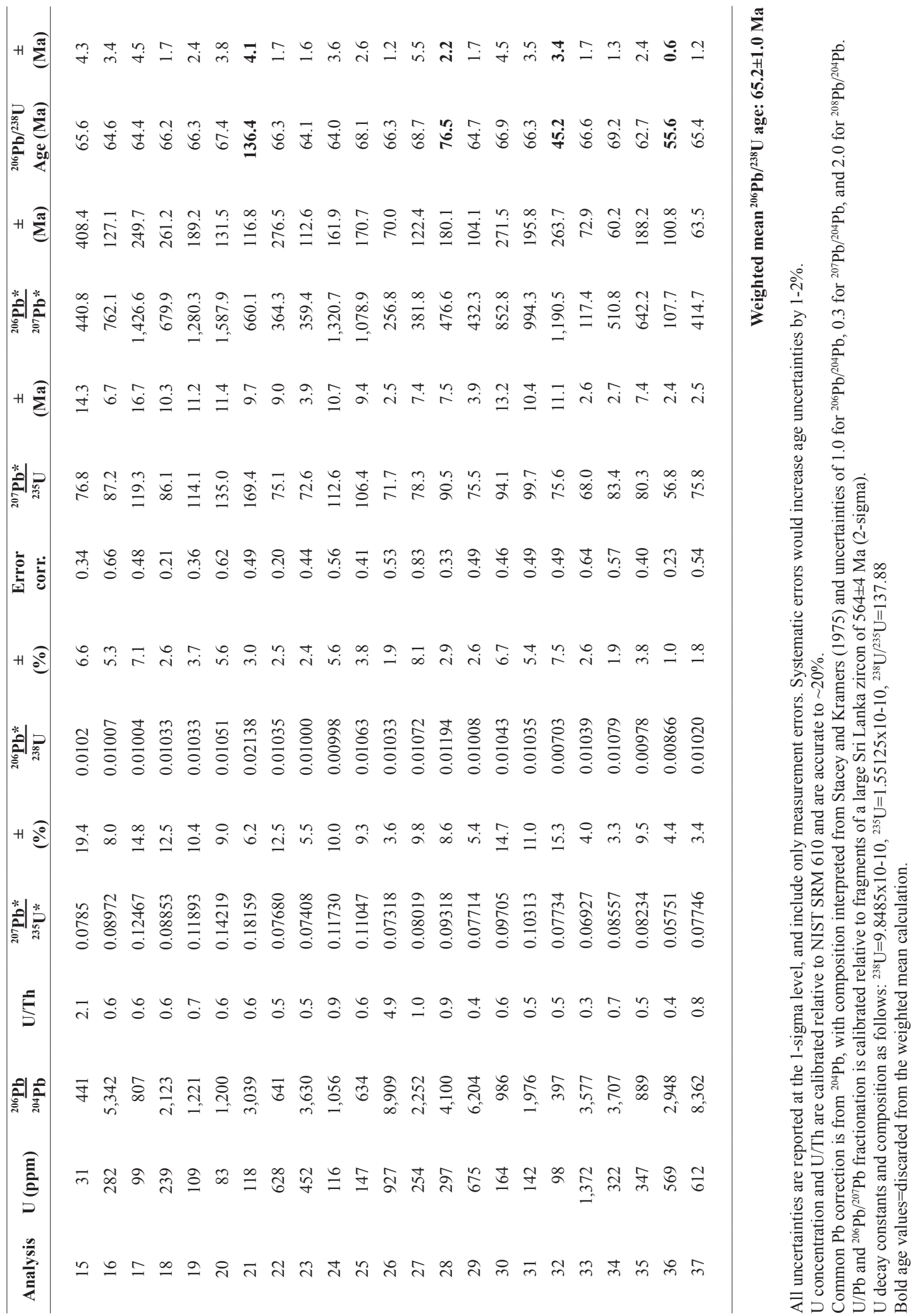

